\title{
HIVgP160 Vaccine
}

National Cancer Institute

\section{Source}

National Cancer Institute. HIVgP160 Vaccine. NCI Thesaurus. Code C29086.

A synthetic HIV vaccine based on a recombinant canary pox virus vector expressing the human immunodeficiency virus (HIV) glycoprotein gp160. HIVgP160 vaccine has been used to generate in vivo primary T lymphocyte response against HIV antigens. (NCI04) 